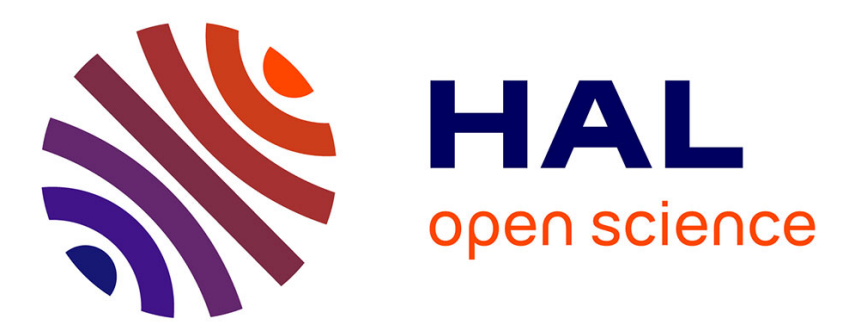

\title{
Effect of wharves on intertidal assemblages on seawalls in Sydney Harbour, Australia
}

David J. Blockley

\section{To cite this version:}

David J. Blockley. Effect of wharves on intertidal assemblages on seawalls in Sydney Harbour, Australia. Marine Environmental Research, 2007, 63 (4), pp.409. 10.1016/j.marenvres.2006.10.007 . hal-00562962

\section{HAL Id: hal-00562962 \\ https://hal.science/hal-00562962}

Submitted on 4 Feb 2011

HAL is a multi-disciplinary open access archive for the deposit and dissemination of scientific research documents, whether they are published or not. The documents may come from teaching and research institutions in France or abroad, or from public or private research centers.
L'archive ouverte pluridisciplinaire HAL, est destinée au dépôt et à la diffusion de documents scientifiques de niveau recherche, publiés ou non, émanant des établissements d'enseignement et de recherche français ou étrangers, des laboratoires publics ou privés. 


\section{Accepted Manuscript}

Effect of wharves on intertidal assemblages on seawalls in Sydney Harbour, Australia

David J. Blockley

PII:

S0141-1136(06)00205-4

DOI:

10.1016/j.marenvres.2006.10.007

Reference:

MERE 3076

To appear in:

Marine Environmental Research

Received Date: $\quad 9$ September 2005

Accepted Date: $\quad 30$ October 2006

Please cite this article as: Blockley, D.J., Effect of wharves on intertidal assemblages on seawalls in Sydney Harbour, Australia, Marine Environmental Research (2006), doi: 10.1016/j.marenvres.2006.10.007

This is a PDF file of an unedited manuscript that has been accepted for publication. As a service to our customers we are providing this early version of the manuscript. The manuscript will undergo copyediting, typesetting, and review of the resulting proof before it is published in its final form. Please note that during the production process errors may be discovered which could affect the content, and all legal disclaimers that apply to the journal pertain. 
1 Effect of wharves on intertidal assemblages on seawalls in Sydney Harbour, Australia

2

4

David J. Blockley

Centre for Research on Ecological Impacts of Coastal Cities, Marine Ecology Laboratories (A11), University of Sydney, New South Wales 2006, Australia.

Telephone: +61293514681

Facsimile: +61293516713

Email: dblockley@eicc.bio.usyd.edu.au

\section{Abstract}

Worldwide, urbanisation has resulted in extensive replacement of natural habitats with manmade habitats. In Sydney Harbour, Australia, approximately half of the natural foreshore has been replaced by seawalls. Many of these have wharves built over part of their length, which could affect intertidal assemblages on seawalls beneath the wharves. This was tested by sampling and comparing assemblages under and not under wharves in Sydney Harbour. Assemblages differed between the two habitats, with greater cover of macro-algae and abundance of grazing molluscs on seawalls without a wharf and, to a lesser extent, greater cover of sessile invertebrates on seawalls under a wharf. There was, however, considerable spatial variability among locations in composition of assemblages and the species dominating differences between the two habitats. The impact of multiple artificial structures in close proximity and the variability among apparently homogeneous artificial habitats must be considered for the management of urbanised estuaries.

\section{Keywords: Algae; Artificial habitats; Coastal structures; Grazing molluscs; Sessile invertebrates} Shading; Sydney Harbour; Temperature; Urbanisation 


\section{Introduction}

Urbanisation of coastal waters has resulted in proliferation of a variety of different artificial marine structures (e.g. pontoons, pilings and seawalls), each supporting different assemblages (Connell \& Glasby, 1999; Glasby \& Connell, 1999). Seawalls are among the most common marine habitat within urbanised estuaries and bays (Davis, Levin \& Walther, 2002; Chapman, 2003), but often have other types of artificial structures built in close proximity, such as wharves (Blockley \& Chapman, In press ). These structures might influence the assemblage living on the seawall by increasing or decreasing abundances or covers of different species.

The sections of seawalls under wharves are potentially subject to different environmental conditions (e.g. light, temperature, rain and wind) to those in the open. Wharves, jetties and similar structures have been found to reduce the growth of seagrasses (Short \& Burdick, 1996; Burdick \& Short, 1999) and density of salt marsh plants (Sanger, Holland \& Gainey, 2004). The effect of wharves and jetties on assemblages living on other artificial habitats has also been examined in subtidal habitats (e.g. for pilings), with reductions in the cover and types of algae in shaded areas and an increase in sessile invertebrates (Glasby, 1999a; 1999b). The effect of wharves on intertidal hard substrata has not, however, received much attention. This is an important consideration because wharves are most profuse in areas that are already urbanised and so are most likely to be built in association with other artificial structures, frequently seawalls (Blockley \& Chapman, In press ).

This study was done in Sydney Harbour, Australia, where most wharves are built over parts of the extensive network of seawalls. Sections of seawalls that were either shaded or unshaded by wharves were predicted to have different assemblages and covers or abundances of individual taxa would differ between shaded or unshaded seawalls. Specifically, it was predicted that; (1) the cover of algae would be greater on unshaded seawalls where there is more light (e.g. Clark, Edwards \& Foster, 2004), (2) grazing invertebrates would be more abundant on unshaded seawalls because this 
53 is where their food source was predicted to be greater and (3) sessile invertebrates would have

54 greater cover on shaded seawalls because they would not have to compete for space with algae, nor be dislodged by mobile invertebrates and might be benefited by the presence of a wharf (e.g. reduction of thermal stress and desiccation). It was also predicted that these patterns would be spatially and temporal consistent throughout Sydney Harbour.

\section{Methods}

This study was done at seven locations in Sydney Harbour: Athol Bay, Cremorne Point, Rushcutters Bay, Hermit Point, Parriwi Head, Little Manly Point and Quarantine Station (Figure 1). All locations had seawalls with adjacent sections either with or without wharves. At each location, one section of seawall, approximately $5 \mathrm{~m}$ wide, under a wharf and one not under a wharf were sampled. Despite considerable variability in the design of wharves in this study, each $5 \mathrm{~m}$ section under a wharf was completely in shade and at least $1 \mathrm{~m}$ from the edge of the wharf. For each section, ten replicate $20 \times 25 \mathrm{~cm}$ quadrats were sampled at the mid- (0.9-1.1 m above chart datum) and low-tidal (0.6 - $0.8 \mathrm{~m}$ above chart datum) heights. Percentage cover of all algae and sessile invertebrates were measured and all mobile invertebrates counted. Where possible, without destructive sampling, organisms were identified to species. Where complexes were formed, so that individual species could not be distinguished (e.g. some of the small foliose algae and sponges), these were assigned to broad groups (e.g. mixture of sponges referred to as "orange sponge"). Sampling was repeated four times; in March, June, October, 2003 and February, 2004. Even though the same sections of seawall were sampled each time, these times are far enough apart to provide independent data (Underwood \& Chapman, 1998; Bulleri, Chapman \& Underwood, 2005). Replicates were sampled randomly across the wall each time, so quadrats were not fixed. At the low-tidal height, only six of the locations were sampled because the lower shore of Parriwi Head was buried by a sand bank after the first sampling. 
Environmental conditions on seawalls under or not under wharves were measured, with incident light on the wall and the surface temperature of the substratum the two variables recorded. These variables were considered to most likely differ between seawalls under or not under a wharf and are known to be important in structuring assemblages. The amount of incident light has a strong influence on the growth and survival of algae (Glasby, 1999a; Goldberg \& Foster 2002; Clark et al., 2004) and recruitment of invertebrates (Pomerat \& Reiner, 1942; Saunders \& Connell, 2001). Incident light was measured (in Lux) using a light meter placed at 10 random areas on seawalls under or not under wharves at each of the 7 locations. Sampling was repeated 5 times each month from April, 2003 until March, 2004.

\section{Surface temperature of the substratum has been closely linked to the body temperature of} many sessile invertebrates (Wethey, 2002) and is an important indirect measure of thermal stress. The surface temperature of the seawall was also recorded for each habitat and location using an infra-red electronic thermometer. This measures the temperature of the surface of the substratum directly and is unaffected by air temperature or whether or not the device is in the sun. As for incident light, 10 random areas were sampled in each habitat for each of the 7 locations, with sampling repeated 5 times each month for a year.

All measurements of light and temperature throughout the sampling period were collected at approximately the same time of day and during low tide. It was not possible to collect incident light data during high tide and it would not have made sense to collect thermal data when organisms were immersed. During high tide, the surface temperature would have been controlled by water temperature and would not have differed between shaded and unshaded seawalls. For each month, there were 50 replicate measures of surface temperature and incident light collected for each habitat and location. These were averaged to give a mean monthly value. Collection of continuous data was not feasible with the resources available over such a large number of sites. There are also many restrictions on what can be attached to seawalls, being publically or privately owned structures. The assemblages were compared using PERMANOVA (Anderson, 2001). Matrices of 
104 dissimilarity among samples were calculated using the Bray-Curtis dissimilarity coefficient (Bray \&

105 Curtis, 1957). The method of permutation used for all analyses was the permutation of residuals

106 under a full model because this gives the best power and accurate Type 1 error while being

107 reasonably quick (Anderson \& Legendre, 1999). Each of the 4 times of sampling was treated as an

108 independent test of the hypothesis that difference between assemblages on seawalls shaded or

109 unshaded by wharves was general to all locations, while in separate analyses each of the 7 locations

110 were used as independent tests of the hypothesis that patterns would be temporally consistent. The

111 data were visualised with nMDS ordinations (Clarke, 1993). Analyses of variance tested hypotheses

112 that covers or abundances of taxa differed between the two habitats (fixed, orthogonal), among

113 locations (random, orthogonal) and through time (random, orthogonal) for algae, mobile

114 invertebrates and sessile invertebrates. Generally, it was found that heterogeneous variances for

115 percentage covers could not be stabilised by transformation and so analyses were done on

116 untransformed data with a more conservative significance level (see tables). ANOVA is, however,

117 robust to heterogeneity of variance and non-normal data and so is an appropriate analytical

118 technique (Underwood, 1999).

119

120 3. Results

121

3.1. Comparisons among assemblages

122

123

graph for each location (Figure 2). Despite some pattern of grouping by habitat, particularly at times

1 and 4, there was a great deal of overlap between habitats shown in the plots among locations (i.e.

125

some points representing assemblages on shaded seawalls plotted close to the cluster of points representing those on unshaded seawalls from different locations (Figure 2)).

There was a significant interaction of Location and Habitat for the mid- and low-tidal

128 heights for the analyses of each time (Table 1a). Therefore, the hypothesis that the patterns of

129 difference would be general to all locations was rejected, although a posteriori pairwise 
130

131

132

133

134

135

136

137

138

139

140

141

142

143

144

145

146

147

148

149

150

151

152

153

154

155

comparisons showed that these habitats were always different for each location. This result is supported by the Bray-Curtis dissimilarities, which show that the dissimilarity between habitats is much greater than the average dissimilarity within each habitat for both tidal heights (Table 2). The dissimilarity among locations for each habitat is also large, supporting the lack of generality of the pattern among locations (hence the variability in Figure 2). Furthermore, the variability among locations for seawalls under wharves was greater than for seawalls not under a wharf at the midtidal height, but similar at the low tidal height (Table 2).

The analyses of each location separately across all times gave interactions between time and habitat for both heights in each location (Table 1b) showing that patterns of difference changed through time. Nevertheless, the plot for each location shows strong separation between habitats across all times indicating differences between the habitats remained large (Figure 3). The temporal changes, illustrated in the nMDS plots, did not show a consistent pattern among locations or between habitats.

\subsection{Comparisons of individual taxa}

Despite no general pattern of difference between habitats for whole assemblages, it was

evident that there were consistent patterns for individual taxa among locations at the mid- (Table 3, Figure 4) and low-tidal height (Table 4, Figure 5). The encrusting alga, Hildenbrandia rubra was the dominant alga at the mid-tidal height (Figure 4a), while the turf, Corallina officinalis or foliose green algae, formed by complex patches of Enteromorpha intestinalis, Ulva lactuca, Cladophora sp., Chaetomorpha sp. and Bryopsis sp., dominated the low-tidal height (Figure 5a). Hildenbrandia rubra showed Time x Location and Location x Habitat interactions (Table 3a) while the low-shore algae had significant Time x Location x Habitat interactions (Table 4a). Despite this, the general patterns did not vary much among times, as shown by Hildenbrandia rubra (Figure 4a). For this reason and for the sake of brevity, only one time is shown to illustrate patterns for the other two alga (Figure 5a). There were large differences in cover among locations and the difference between 
156

157

158

159

160

161

162

163

164

165

166

167

168

169

170

171

172

173

174

175

176

177

178

179

180

181

habitats was only significant at some times and locations, but there was a strong pattern of greater cover on seawalls not under wharves (Figure 4a \& 5a). Binomial tests indicated that, despite the lack of significant differences at some locations or times, the general pattern was significant (Figure 4a \& 5a).

The oyster Saccostrea glomerata was the dominant sessile invertebrate at most locations at the mid-tidal height. The mussel Mytilus galloprovincialis, the tubeworm Galeolaria caespitosa, the barnacles Tesseropora rosea and Tetraclitella purpurascens and an encrusting orange sponge also had relatively large covers at many locations (Figure $4 b$ ). The pattern was similar at the low-tidal height, although $S$. glomerata was not as dominant and the barnacle Austrobalanus imperator was also present (Figure 5b). As for the algae, there were significant Time $\mathrm{x}$ Location $\mathrm{x}$ Habitat interactions for most analyses of cover of sessile invertebrates (Table $3 b$ \& $4 b$ ). Exceptions were $M$. galloprovincialis at the mid-tidal height and A. imperator and T. rosea at the low-tidal height, which showed higher-order interactions. Despite this, the patterns were fairly consistent through time, shown for S. glomerata and so only one time is presented for the remaining taxa to illustrate the pattern (Figure 4b). There was, however, considerable difference in the covers of the various species among locations.

Covers of $S$. glomerata were most consistent among locations mid-tidally and were significantly greater on seawalls that were not under a wharf (binomial tests, Figure 4b). This is opposite to the pattern predicted. Similarly, mid-tidally $T$. rosea had a greater cover on seawalls not under wharves at many locations, although the general pattern was not significant (Figure 4b). The other sessile invertebrates showed the predicted pattern of greater covers on seawalls under wharves at many, but not all locations, however the difference was still significant (Figure 4b). The cover of S. glomerata, M. galloprovincialis, G. caespitosa, and A. imperator did not differ between habitats significantly at the low-tidal height, although the cover of A. imperator was significantly greater on walls under wharves at Athol Bay and Cremorne Point at all times (Table 4b, Figure 5b). T. rosea showed a significant pattern, although as for the mid-tidal height, it was 
182 opposite to that predicted (Figure 5b). T. purpurascens and orange sponge, however, showed a

183 significant pattern of greater cover on walls under wharves as predicted (Figure 5b).

184 Of the mobile invertebrates, only Chiton pelliserpentis and the limpet, Siphonaria

185 denticulata occurred in large enough numbers to be analysed. Analyses showed that each were

186 more abundant on walls not under a wharf, although not significantly at all locations or times (Table

187 3c, Figure 6). Nevertheless the general pattern was consistent through time (Figure 6). There were

188 many locations with a significantly greater abundance of both species on unshaded seawalls (Table

189 3c, Figure 6), although, at some times and locations, the opposite was found. Despite this, the

190 predicted pattern of greater abundance of grazing invertebrates was significant (Figure 6).

191

192

193

194

195

196

197

198

199

200

201

202

203

\subsection{Measurements of surface temperature and light on seawalls}

The mean surface temperature on walls not under wharves was greater than on walls under wharves at each location (Figure 7). Nevertheless, the magnitude of the difference between the two habitats was not consistent among locations (e.g. the difference between the two habitats at Athol Bay was relatively small, while the difference at Hermit Point was much larger). There was also a difference in range of mean temperatures among locations (e.g. the seawall not under a wharf at Rushcutters Bay had a maximum temperature of approximately $28^{\circ} \mathrm{C}$, while the same habitat at Cremorne Point was about $23^{\circ} \mathrm{C}$ ).

Despite the mean surface temperature on seawalls not under wharves being greater than that on walls under wharves, the magnitude of the difference in temperature between habitats changed through time. The greatest difference was in the Austral summer months (December through to February), when the greatest mean surface temperatures were recorded.

The change in mean light, measured in Lux, on seawalls shows some similarity to the pattern seen for mean temperature (Figure 8). Incident light was, as would be expected, greater on seawalls not under wharves at all locations and at all times. There was considerable variability among locations in the magnitude of difference between the two habitats, as well as the range of 
208

values recorded and a great deal of variability through time. Unlike temperature, there was no easily discernible pattern for the temporal variability of the light. There did not appear to be a consistent pattern among locations or in relation to seasonal change.

\section{Discussion}

In the current study, algae were virtually absent from walls under wharves and there was considerable covers of algae, such as Corallina officinalis and foliose green algae (e.g.

Enteromorpha intestinalis), on unshaded seawalls. Shade can be important in structuring assemblages and has been shown to have important effects on the growth and survival of terrestrial plants (Weih \& Karlsson, 1987; Valladares \& Pearcy, 1997; Sans, Escarré, Lepart, \& Hopkins, 2002), marine algae (Glasby, 1999b; Goldberg \& Foster, 2002; Clark et al, 2004) seagrasses (Burdick \& Short, 1999) and saltmarsh (Sanger et al., 2004). Animals on intertidal shores have also been shown to be affected by shading, with greater recruitment or survival where there is shade (Denley \& Underwood, 1979; Harper \& Williams, 2001). Shading alone may, therefore, explain the absence of algae and the greater cover of most species of sessile invertebrates under wharves in the present study, although this can not be concluded categorically without manipulative experiments.

Unlike many other sessile invertebrates in this study, the barnacle $T$. rosea had greater cover on unshaded walls. Denley \& Underwood (1979) found that T. rosea would settle on unshaded and shaded shores, but survived better in the sun. The oyster S. glomerata, one of the dominant space occupiers, also had greater cover on unshaded walls. Bulleri et al. (2005) found that S. glomerata was able to dominate space on seawalls in Sydney Harbour, although the pattern was variable among locations. Beds of $S$. glomerata can be quite thick, providing oysters with protection from environmental extremes (e.g. thermal stress) in a similar way to the presence of a wharf. The lesser cover of other sessile invertebrates on unshaded seawalls may also have meant that oysters had less competition for space and so were able to maintain greater covers than on shaded seawalls. 
The present study has shown that there is less incident light reaching seawalls with wharves

234 compared to sections without wharves. Glasby (1999b) found that the degree of shading may be

235 important in structuring assemblages of epibiota on subtidal pier pilings, with similar results as in

236 the present study. The amount of shade can also influence the surface temperature of rocky

237 intertidal areas, with unshaded areas having much greater surface temperatures than adjacent shaded

238 areas during low-tide leading to physiological affects (e.g. greater mortality through desiccation or

239 thermal stress (Garrity, 1984; Harper \& Williams, 2001)). The provision of shade can ameliorate

240 thermal stress and increase recruitment and survival (Denley \& Underwood, 1979; Williams, 1994;

241 Bertness, Leonard, Levine, \& Bruno, 1999). According to Helmuth and Hofmann (2001), however,

242 it is extreme temperature events (extremes of heat and cold) rather than the mean temperature that

243 causes physiological stress. The design of the experiment was unlikely to capture temperature

244 extremes because it unavoidably involved "snap-shot" measurements. The data collected does give

245 a good indication that these extreme high temperatures would occur on unshaded seawalls, where

246 surface temperature was always greater, whereas wharves would buffer seawalls beneath them from 247 these events.

Recruitment of algae and invertebrates to seawalls has been shown to be affected by wharves, which shade the wall directly under them (Blockley \& Chapman, In press ). The greater cover of most sessile animals in the lower light conditions under wharves might represent a negative phototactic response at the time of settlement (e.g. Pomerat \& Reiner, 1942; Wisely, 1959). O'Donnell (1984) showed that G. caespitosa recruit in greater numbers to shaded habitats, possibly explaining the patterns in the current study. Algae has also been shown to have greater recruitment to unshaded habitats (Goldberg \& Foster, 2002; Clark et al, 2004). It is, therefore, possible that the patterns found in the present study are determined at the time of recruitment rather than by post-recruitment processes. under wharves, there was great variability among locations and to, a lesser extent, among times. 
259

260

261

262

263

264

265

266

267

268

269

270

271

272

273

274

275

276

277

278

280

281

282

283

284

Large-scale spatial (at the scale of $\mathrm{km}$ ) and temporal differences in intertidal assemblages are a feature of the rocky shores of New South Wales, Australia (Dakin, Bennett, \& Pope, 1948; Underwood \& Chapman, 1998; Benkendorff \& Davis, 2002). However, seawalls, unlike rocky shore, are homogeneous structures and so would be predicted to be less variability among locations. Previous research on seawalls in Sydney Harbour by Bulleri et al. (2005) has, however, shown that the variability of assemblages on seawalls can be as great as, or greater than that found on rocky shores among locations. Although Bulleri et al. (2005) found that the taxa responsible for patterns on seawalls varied among locations, general patterns were consistent for each location,. This is similar to the present study, with assemblages consistently differing between the shaded and unshaded seawalls at each location, but species responsible for patterns differing, resulting in the overall variability among locations. In their study, Bulleri et al. (2005) only examined three locations and did not directly compare among locations. The present study has therefore expanded on this by examining a greater number of locations, comparing among locations and studying a common, yet so far largely ignored, artificial habitat, that is seawalls under wharves.

One explanation for the large-scale spatial variability is that the orientation and position within the harbour of seawalls differed among locations, such that physical conditions on the seawalls could have varied among locations. Seawalls that faced north, for example, would be subject to more direct sunlight than those facing south, resulting in greater surface temperatures. This is evident in the measures of incident light and surface temperature of unshaded seawalls (e.g. Hermit Point and Quarantine Station, north facing wall, compared to Cremorne Point and Athol Bay, south facing wall). In locations where seawalls were oriented towards the sun, the difference in temperature between shaded and unshaded seawalls would be expected to be greater than where seawalls were not oriented towards the sun. In the present study, the difference in temperature between shaded and unshaded sections of seawall that faced north, towards the sun, was up to $10^{\circ} \mathrm{C}$, while the difference between habitats for south facing walls was less than $5^{\circ} \mathrm{C}$. This could explain some of this dissimilarity in the composition of assemblages among locations. 
Urbanised waterways are heavily impacted by anthropogenic activity, with many sources of

286 disturbance (Kullenberg, 2001; Vallega, 2001; Kennish, 2002). The multiple impacts of artificial

287 structures built on, or in the vicinity of, other artificial structures and the additive effects of their associated impacts has generally been overlooked in studies of disturbance ecology. Although this

study did not examine how the assemblages associated with two different types of artificial

structures (i.e. seawalls and wharves) differed from those on natural shores, previous studies have

shown that assemblages differ between seawalls and natural shores (Chapman \& Bulleri, 2003;

Chapman, 2003; Bulleri et al., 2005). The present study has shown that the presence of another

structure (wharves) can further alter assemblages on seawalls. Whether the difference to

assemblages on seawalls caused by the presence of wharves translates to making assemblages more

or less different from those on natural shores is an area of further study.

The potential of wharves to provide or alter habitats for marine organisms needs to consider

the possible positive effects against negative impacts. The presence of a wharf not only means that

the composition of assemblages or relative covers or abundances of taxa differs from adjacent

unshaded seawalls, but also results in assemblages that are more variable at small and large spatial

scales. The shaded surfaces may act as substitutes for microhabitats that are missing from seawalls,

as well as adding to the amount and variety of habitats because of structures, such as pilings,

considered. If seawalls with wharves do not support assemblages that are representative of those on natural shores, then they cannot necessarily be said to have a positive impact, regardless of 
309

\section{Acknowledgments}

311 This study was supported by the Australian Research Councils Special Centres Programme and the

312 University of Sydney Postgraduate Awards. Gee Chapman, Vicky Cole, Paris Goodsell and two

313 anonymous referees offered useful comments on an earlier draft of this manuscript. 
314

315

316

317

318

319

320

321

322

323

324

325

326

327

328

329

330

331

332

333

334

335

336

337

338

339

\section{References}

Anderson, M. J., (2001). A new method for non-parametric multivariate analysis of variance. Austral Ecology, 26, 32-46.

Anderson, M. J. \& Legendre, P., (1999). An empirical comparison of permutation methods for tests of partial regression coefficients in a linear model. Journal of Statistical Computer Simulation, 62, 271-303.

Benkendorff, K. \& Davis, A. R., (2002). Identifying hotspots of molluscan species richness on rocky intertidal reefs. Biodiversity and Conservation, 11, 1959-1973.

Bertness, M. D., Leonard, G. H., Levine, J. M. \& Bruno, J. F., (1999). Climate-driven interactions among rocky intertidal organisms caught between a rock and a hot place. Oecologia, 120, 446-450.

Blockley D. J., Chapman M. G. (In press) Does recruitment determine differences between assemblages on shaded or unshaded seawall? Marine Ecology Progress Series.

Bray, J. R. \& Curtis, J. T., (1957). An ordination of the upland forest communities of Southern Wisconsin. Ecological Monographs, 27, 325-349.

Bulleri, F., Chapman, M. G. \& Underwood, A. J., (2005). Intertidal assemblages on seawalls and vertical rocky shores in Sydney Harbour (Australia). Austral Ecology, 30, 655-667.

Burdick, D. M. \& Short, F. T., (1999). The effects of boat docks on eelgrass beds in coastal waters of Massachusetts. Environmental Management, 23, 231-249. 
341 Chapman, M. G., (2003). Paucity of mobile species on constructed seawalls: effects of urbanization 342 on biodiversity. Marine Ecology Progress Series, 264, 21-29.

Chapman, M. G. \& Bulleri, F., (2003). Intertidal seawalls: new features of landscape in intertidal environments. Landscape and Urban Planning, 62, 159-172.

Clark, R. P., Edwards, M. S. \& Foster, M. S., (2004). Effects of shade from multiple kelp canopies on an understory algal assemblages. Marine Ecology Progress Series, 267, 107-119.

Clarke, K. R., (1993). Non-parametric multivariate analysis of changes in community structure. Australian Journal of Ecology, 18, 117-143.

Cole, V.J., Glasby, T.M. \& Holloway, M.G. (2005). Extending the generality of ecological models to artificial floating habitats. Marine Environmental Research, 60, 195-210.

Dakin, W. J., Bennett, I. \& Pope, E., (1948). A study of certain aspects of the ecology of the intertidal zone of the New South Wales coast. Australian Journals of Scientific Research, Series B, $1,176-230$. coast species in a southern California bay. Marine Biology, 140, 1249-1262. 
367 Denley, E. J. \& Underwood, A. J., (1979). Experiments on factors influencing settlement, survival, 368 and growth of two species of barnacles in New South Wales. Journal of Experimental Marine 369 Biology and Ecology, 36, 269-293.

370

Garrity, S. D., (1984). Some adaptations of gastropods to physical stress on a tropical rocky shore.

372 Ecology, 65, 559-574.

373

374 Glasby, T. M., (1999a). Differences between subtidal epibiota on pier pilings and rocky reef at 375 marinas in Sydney, Australia. Estuarine, Coastal and Shelf Science,48, 281-290.

376

Glasby, T. M., (1999b). Effects of shading on subtidal epibiotic assemblages. Journal of Experimental Marine Biology and Ecology, 234, 275-290.

Glasby, T. M. \& Connell, S. D., (1999). Urban structures as marine habitats. Ambio, 28, 595-598.

Goldberg, N. A. \& Foster, M. S., (2002). Settlement and post-settlement processes limit the Marine Biology and Ecology, 278, 31-45.

Harper, K. D. \& Williams, G. A., (2001). Variations in abundance and distribution of the chiton Zoology, 253, 293-300. 
393 Kennish, M. J., (2002). Environmental threats and environmental future of estuaries. Environmental 394 Conservation, 29, 78-107.

395

396 397 398

400

401

402

403

404 405 406 407 408 409 410 411 412 413 414

415 416 417

Kullenberg, G., (2001). Contributions of marine and coastal area research and observations towards sustainable development of large cities. Ocean and Coastal Management, 44, 283-291.

O'Donnell, M. A. (1984) Aspects of the ecology of the serpulid tubeworm, Galeolaria caespitosa (Polychaeta: Serpulidae). In P.A. Hutchings, Proceedings of the First International Polychaete Conference, Sydney (pp. 355-360). Sydney: Linnean Society of New South Wales.

Pomerat, C. M. \& Reiner, E. R., (1942). The influence of surface angle and light on the attachment of barnacles and other sedentary organisms. Biological Bulletin, 82, 14-25.

Sanger, D. M., Holland, A. F. \& Gainey, C., (2004). Cumulative impacts of dock shading on Spartina alterniflora in South Carolina estuaries. Environmental Management, 33, 741-748.

Sans, F. X., Escarré, J., Lepart, J. \& Hopkins, F., (2002). Positive vs. negative interactions in Picris hieracioides L., a mid-successional species of Mediterranean secondary succession. Plant Ecology, $162,109-122$.

Saunders, R.J. and Connell, S.D., (2001). Interactive effects of shade and surface orientation on the recruitment of spirorbid polychaetes. Austral Ecology 26, 109-115.

Short, F. T. and Burdick, D. M., (1996). Quantifying eelgrass habitat loss in relation to housing development and nitrogen loading in Waquoit Bay, Massachusetts. Estuaries 19, 730-739. 
Underwood, A. J., (1999). Experiments in Ecology. Their logical design and interpretation using analysis of variance. Cambridge University Press, Cambridge, UK.

Underwood, A. J. \& Chapman, M. G., (1998). Spatial analyses of intertidal assemblages on sheltered rocky shores. Australian Journal of Ecology, 23, 138-157.

Underwood, A. J. and Denley, E. J. (1984). Paradigms, explanations, and generalisations in models for the structure of intertidal communities on rocky shores. In D. R. Strong, D. Simberloff, L.G. Abele \& A. Thistle, Ecological communities: conceptual issues and the evidence (pp. 151-80). New Jersey: Princeton University Press.

Valladares, F. \& Pearcy, R. W., (1997). Interactions between water stress, sun-shade acclimation, heat tolerance and photoinhibition in the sclerophyll Heteromeles arbutifolia. Plant, Cell and Environment, 20, 25-36.

Vallega, A., (2001). Urban waterfront facing integrated coastal management. Ocean and Coastal Management, 22, 379-410.

Weih, M. \& Karlsson, P. S., (1987). The nitrogen economy of mountain birch seedlings: implications for winter survival. Journal of Ecology, 87, 211-219.

Wethey, D. S., (2002). Biogeography, competition, and microclimate: the barnacle Chthamalus fragilis in New England. Integrative and Comparative Biology, 42, 872-880.

Williams, G. A., (1994). The relationship between shade and molluscan grazing in structuring communities on a moderately-exposed tropical rocky shore. Journal of Experimental Marine 
444 Biology and Ecology, 178, 79-95.

445

446 Wisely, B., (1959). Factors influencing the settling of the principal marine fouling organisms in

447 Sydney Harbour. Australian Journal of Marine and Freshwater Research, 10, 30-44. 
448

449

450

451

452

453

454

455

456

457

458

459

460

461

462

463

464

465

Table 1. Results from analyses by non-parametric MANOVA on assemblages on sections of seawall under or not under wharves (a) among locations for each time of sampling and (b) through time at each location, at mid-and low-tidal heights. 5000 permutation of residuals were used for all analyses. NS $=P>0.05$, * $=P<0.05$, ** $=P<0.01$, *** $=P<$ 0.001 .

(a)

Mid-tidal height

\begin{tabular}{cccccc} 
Source & df & $F$ & $F$ & $F$ & $F$ \\
& Time 1 & Time 2 & Time 3 & Time 4 \\
\hline
\end{tabular}

Location $=\mathrm{L} \quad 6$

Habitat $=\mathrm{H}$

$\mathrm{L} \times \mathrm{H}$

$23.84 * * *$

$18.23 * * *$

$15.14 * * *$

$14.28 * * *$

Residual

126

Low-tidal height

Source

df $F$

Time 1

F

F

Time 3

Time 2

Time 3 Time 4

Location

Habitat

L x H

Residual

$-$

$12.10 * * *$

$10.98 * * *$

$10.03 * * *$

$11.13 * * *$

119

(b)

Mid-tidal Height

Source df

df $F$

$\begin{array}{ccc}F & F & F\end{array}$

Athol Cremorne Rushcutters Hermit Parriwi Little Quarantine

Time $=\mathrm{T} \quad 3$

Bay

Point

Bay

Point Head

Habitat $=\mathrm{H} \quad 1$

$\mathrm{T} \times \mathrm{H}$

$3.54 * * * \quad 11.07 * * *$

$5.14 * * * \quad 6.75 * * *$

$4.71 * * * \quad 2.64 * *$

$3.53 * * *$

Residual 72

Low-tidal Height

\begin{tabular}{lrcccccc}
\hline Source & df & $\begin{array}{c}F \\
\text { Athol } \\
\text { Bay }\end{array}$ & $\begin{array}{c}\text { Cremorne } \\
\text { Point }\end{array}$ & $\begin{array}{c}F \\
\text { Rushcutters } \\
\text { Bay }\end{array}$ & $\begin{array}{c}F \\
\text { Hermit } \\
\text { Point }\end{array}$ & $\begin{array}{c}F \\
\text { Little } \\
\text { Manly Pt }\end{array}$ & $\begin{array}{c}F \\
\text { Quarantine } \\
\text { Station }\end{array}$ \\
\hline Time & 3 & & & & & & \\
Habitat & 1 & & & & & $6.66^{* * *}$ & $5.98^{* * * *}$ \\
T x H & 3 & $3.18 * * *$ & $2.80 * * *$ & $7.55 * * *$ & $8.39 * * *$ & & \\
Residual & 72 & & & & & & \\
\hline
\end{tabular}


466 Table 2. Average Bray-Curtis dissimilarities within and among locations for each habitat and between the two habitats 467 at each time for mid- and low-tidal height. W= Wharf and NW = No-wharf habitats.

468

Mid-tidal height

\begin{tabular}{|c|c|c|c|c|c|}
\hline & \multicolumn{2}{|c|}{ WHARF } & \multirow{2}{*}{$\begin{array}{c}\text { Between } \\
\text { W/NW }\end{array}$} & \multicolumn{2}{|c|}{ NO-WHARF } \\
\hline & Within & Among & & Within & Among \\
\hline Time 1 & 41.2 & 75.9 & 71.4 & 23.1 & 64.0 \\
\hline Time 2 & 41.5 & 80.2 & 74.4 & 29.3 & 60.6 \\
\hline Time 3 & 44.5 & 82.9 & 72.6 & 27.2 & 50.5 \\
\hline Time 4 & 48.0 & 85.2 & 79.6 & 36.9 & 60.4 \\
\hline
\end{tabular}

Low-tidal height

\begin{tabular}{|c|c|c|c|c|c|}
\hline & \multicolumn{2}{|c|}{ WHARF } & \multirow{2}{*}{$\begin{array}{c}\text { Between } \\
\text { W/NW }\end{array}$} & \multicolumn{2}{|c|}{ NO-WHARF } \\
\hline & Within & Among & & Within & Among \\
\hline Time 1 & 58.6 & 85.0 & 90.1 & 38.5 & 79.2 \\
\hline Time 2 & 54.4 & 85.4 & 78.0 & 44.7 & 87.5 \\
\hline Time 3 & 61.0 & 87.3 & 88.5 & 45.5 & 79.3 \\
\hline Time 4 & 52.7 & 83.9 & 83.3 & 48.5 & 82.7 \\
\hline
\end{tabular}


469 Table 3. Analyses of individual taxa of (a) algae, (b) sessile invertebrates and (c) mobile invertebrates on sections of 470 seawall under or not under wharves at the mid-tidal height.

471

(a)

Source

Time $=\mathrm{T}$

Location $=\mathrm{L}$

Habitat $=\mathrm{H} \quad 1$

Tx L 18

Tx 3

$\mathrm{LxH} \quad 6$

Tx L x H 18

Residual 504

Transformation

Cochran's test

\begin{tabular}{rl} 
H. rubra & \\
\hline $\mathrm{MS}$ & $F$ \\
178.1 & \\
3767.1 & \\
10386.8 & \\
281.8 & $2.7 *$ \\
85.4 & $0.4 \mathrm{NS}$ \\
3333.0 & $14.1 *$ \\
237.1 & $2.3 \mathrm{NS}$ \\
104.3 & \\
None & \\
$* *$ &
\end{tabular}

(b)

\begin{tabular}{lrrr} 
Source & df & MS & $F$ \\
\cline { 3 - 4 } Time = T & 3 & 2795.5 & \\
Location = L & 6 & 49571.3 & \\
Habitat = H & 1 & 207587.9 & \\
T x L & 18 & 1481.0 & \\
T x H & 3 & 927.3 & \\
L x H & 6 & 13918.3 & \\
T x L x H & 18 & 1683.8 & $5.9 *$ \\
Residual & 504 & 286.0 & \\
Transformation & None & \\
Cochran's test & *
\end{tabular}

\begin{tabular}{|c|c|c|c|c|c|}
\hline \multirow[b]{2}{*}{ Source } & \multirow[b]{2}{*}{ df } & \multicolumn{2}{|c|}{ T. purpurascens } & \multicolumn{2}{|c|}{ Orange sponge } \\
\hline & & MS & $F$ & MS & $F$ \\
\hline Time & 3 & 441.0 & & 26.0 & \\
\hline Location & 6 & 13137.8 & & 124.3 & \\
\hline Habitat & 1 & 40683.8 & & 536.3 & \\
\hline $\mathrm{T} \times \mathrm{L}$ & 18 & 243.7 & & 18.5 & \\
\hline $\mathrm{T} \times \mathrm{H}$ & 3 & 639.4 & & 27.2 & \\
\hline $\mathrm{L} \times \mathrm{H}$ & 6 & 10876.1 & & 113.6 & \\
\hline $\mathrm{T} \times \mathrm{L} \times \mathrm{H}$ & 18 & 313.8 & 3.2 & 18.6 & $3.2 *$ \\
\hline Residual & 504 & 97.5 & & 5.9 & \\
\hline Transform & & None & & None & \\
\hline Cochran's & $\rightarrow$ & $* *$ & & $* *$ & \\
\hline
\end{tabular}

(c)

Source

Time

Location

\begin{tabular}{c} 
C. pelliserpentis \\
\hline MS F \\
3.5 \\
9.1 \\
11.4 \\
1.3
\end{tabular}

S. denticulata

Habitat

T x L

$\mathrm{T} \times \mathrm{H}$

$\mathrm{L} \times \mathrm{H}$

T x L x H

7.1

$1.25 .4 * * *$

0.2

Transformation

Cochran's test

$\operatorname{Ln}(X+1)$

MS F

1.3

2.0

11.8

0.5

0.2

$$
5.9
$$$$
0.82 .9 * * *
$$$$
0.3
$$

$\operatorname{Ln}(X+1)$

NS $\frac{\text { M. galloprovincialis }}{\text { MS F }}$

42.8

1469.9

1980.2

$29.21 .2 \mathrm{NS}$

$68.41 .2 \mathrm{NS}$

1329.222 .6 *

$58.92 .4 \mathrm{NS}$

25.0

None

**

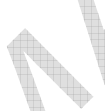

None
$* *$ $\frac{\text { G. caespitosa }}{\mathrm{MS}}$

1767.6

6301.4

13519.5

646.6

1823.2

11220.4

730.04 .14 *

176.2
T. rosea

35.8

2151.8

192.5

18.9

224.1

82.1

$199.95 .1 *$

39.0

None

** because these cannot be logically interpreted. NS $=P>0.05$, * $=P<0.05$, ** $=P<0.01$, *** $=P<0.001$ except where Cochran's test was significant (for $C$ with $P<0.05, *=P<0.01$, ** $=P<0.001$; for $C$ with $P<0.01, *=P<0.001$ ) 
475 Table 4. Analyses of individual taxa of (a) algae and (b) sessile invertebrates on sections of seawall under or not under 476 wharves at the low-tidal height.

477

(a)

Source

Time $=\mathrm{T}$

Location $=\mathrm{L} \quad 5$

Habitat $=\mathrm{H} \quad 1$

Tx L 15

$\mathrm{T} \times \mathrm{H}$

Lx H 5

Tx L x H 15

Residual 432

Transformation

Cochran's test
C. officinalis

MS

4468.2

10590.6

76329.8

1163.2

4446.4

10518.0

1164.76 .5 *

179.4

None

**
Foliose green algae

4.2

13.3

44.7

3.9

7.5

5.5

$2.77 .1 *$

0.4 (b)

Source

Time $=\mathrm{T}$

Location $=\mathrm{L}$

Habitat $=\mathrm{H}$

$\mathrm{T} \times \mathrm{L}$

$\mathrm{T} \times \mathrm{H}$

$\mathrm{LxH}$

T x L x H

Residual

Pooled

Transformation

Cochran's test
S. glomerata

\begin{tabular}{rrr} 
& \multicolumn{2}{l}{ S. glomerata } \\
\cline { 2 - 3 } 3 & MS & $F$ \\
5 & 2129.6 & \\
1 & 10070.7 & \\
15 & 8535.0 & \\
3 & 2270.7 & \\
5 & 6362.0 & \\
15 & 7786.4 & \\
32 & 2610.3 & $10.1 *$ \\
& 259.3 &
\end{tabular}

None

**

Source

Time

Location

Habitat

T x L

$\mathrm{T} \times \mathrm{H}$

$\mathrm{L} \times \mathrm{H}$

T x L x H

Residual

Pooled

Transformation

Cochran's test
T. rosea

\begin{tabular}{|c|c|c|}
\hline \multirow[b]{2}{*}{ df } & \multicolumn{2}{|l|}{ T. rosea } \\
\hline & MS & $F$ \\
\hline 3 & 110.4 & \\
\hline 5 & 809.5 & \\
\hline 1 & 145.8 & \\
\hline 15 & 109.8 & $4.3 *$ \\
\hline 3 & 18.0 & $0.7 \mathrm{NS}$ \\
\hline 5 & 105.7 & $4.1 *$ \\
\hline 15 & ${ }^{\mathrm{P}} 19.5$ & \\
\hline & 25.9 & \\
\hline & 25.7 & \\
\hline
\end{tabular}

$\frac{\text { T. purpurascens }}{\text { MS F }}$

12.4

1252.6

3370.8

285.4

10.3

1084.2

$289.27 .9 *$

74.4

None
G. caespitosa

MS
977.9

3987.7

1117.3

415.9

58.1

2347.6

316.0

122.0

None

**

Orange sponge

$\begin{array}{rr}\text { MS } & F \\ 45.2 & \\ 6107.6 & \\ 18710.1 & \\ 258.2 & \\ 107.1 & \\ 4437.5 & \\ 364.3 & 3.2 * \\ 113.5 & \end{array}$

None

${ }^{\mathrm{P}}$ indicates pooling $(P>0.25)$. Where analyses showed significant interactions, $F$-ratios are not given for main effects and lower order interactions because these cannot be logically interpreted. Because Cochran's test was significant $(P<$ 0.01 ) a conservative significance level was used was used NS $=P>0.01$, $*=P<0.001$ 
482

483

484

485

486

487

Figure 1. Map of field sites within Sydney Harbour, Australia

\section{Figure captions}

Figure 2. nMDS ordination of centroids of assemblages on seawalls under wharves (filled shapes) or not under wharves (empty shapes) at each location: Athol Bay (circle); Cremorne Point (square);

Rushcutters Bay (downward triangle); Hermit Point (upward triangle); Parriwi Head (diamond);

Little Manly Point (small circle); Quarantine Station (small square). Each sampling times and height is graphed separately.

Figure 3. nMDS ordination of centroids of assemblages on seawalls under wharves (circles) or not under wharves (squares) through time (1-4) for selected locations as examples of general patterns at the mid- and low-tidal heights.

Figure 4. Mean (+SE) percentage cover of algae and sessile invertebrates on seawalls under (shaded) or not under (hashed) wharves at the mid-tidal height. Only one time is shown to illustrate general patterns, except for $H$. rubra and $S$. glomerata $. \mathrm{A}=$ Athol Bay; $\mathrm{C}=$ Cremorne Point; $\mathrm{R}=$ Rushcutters Bay; H = Hermit Point; P = Parriwi Head; $\mathrm{M}=$ Little Manly Point; $\mathrm{Q}=$ Quarantine Station. Text in bold indicate number of times the mean was greater under a wharf (W) or where there was no wharf $(\mathrm{NW})$, with number of these that were significantly greater, from SNK tests, given in brackets. $P$ values (with number of comparisons in subscript) are from binomial tests of means.

Figure 5. Mean (+SE) percentage cover of algae and sessile invertebrates on seawalls under (shaded) or not under (hashed) wharves at the low-tidal height. Only one time is shown to illustrate general patterns. $\mathrm{A}=$ Athol Bay; $\mathrm{C}=$ Cremorne Point; $\mathrm{R}=$ Rushcutters Bay; $\mathrm{H}=$ Hermit Point; $\mathrm{M}=$ 
508 Little Manly Point; Q = Quarantine Station. Text in bold indicate number of times the mean was

509 greater under a wharf $(\mathrm{W})$ or where there was no wharf $(\mathrm{NW})$, with number of these that were

510 significantly greater, from SNK tests, given in brackets. $P$ values (with number of comparisons in

511 subscript) are from binomial tests of means.

512

513 Figure 6. Mean (+SE) abundance of mobile invertebrates on seawalls under (shaded) or not under

514 (hashed) wharves at the mid-tidal height. $\mathrm{A}=$ Athol Bay; $\mathrm{C}=$ Cremorne Point; $\mathrm{R}=$ Rushcutters

515 Bay; $\mathrm{H}=$ Hermit Point; $\mathrm{P}=$ Parriwi Head; $\mathrm{M}=$ Little Manly Point; $\mathrm{Q}=$ Quarantine Station. Text in

516 bold indicate number of times the mean was greater under a wharf (W) or where there was no wharf

517 (NW), with number of these that were significantly greater, from SNK tests, given in brackets. $P$

518 values (with number of comparisons in subscript) are from binomial tests of means.

520 Figure 7. Mean surface temperature ( \pm S.E.) of seawalls under (circle, solid line) or not under

521 (triangle, hashed line) wharves at each location from April 2003 until March 2004.

Figure 8. Mean light (Lux) on seawalls under (circle, solid line) or not under (triangle, hashed line)

524 wharves at each location from April 2003 until March 2004. 
525 Fig. 1
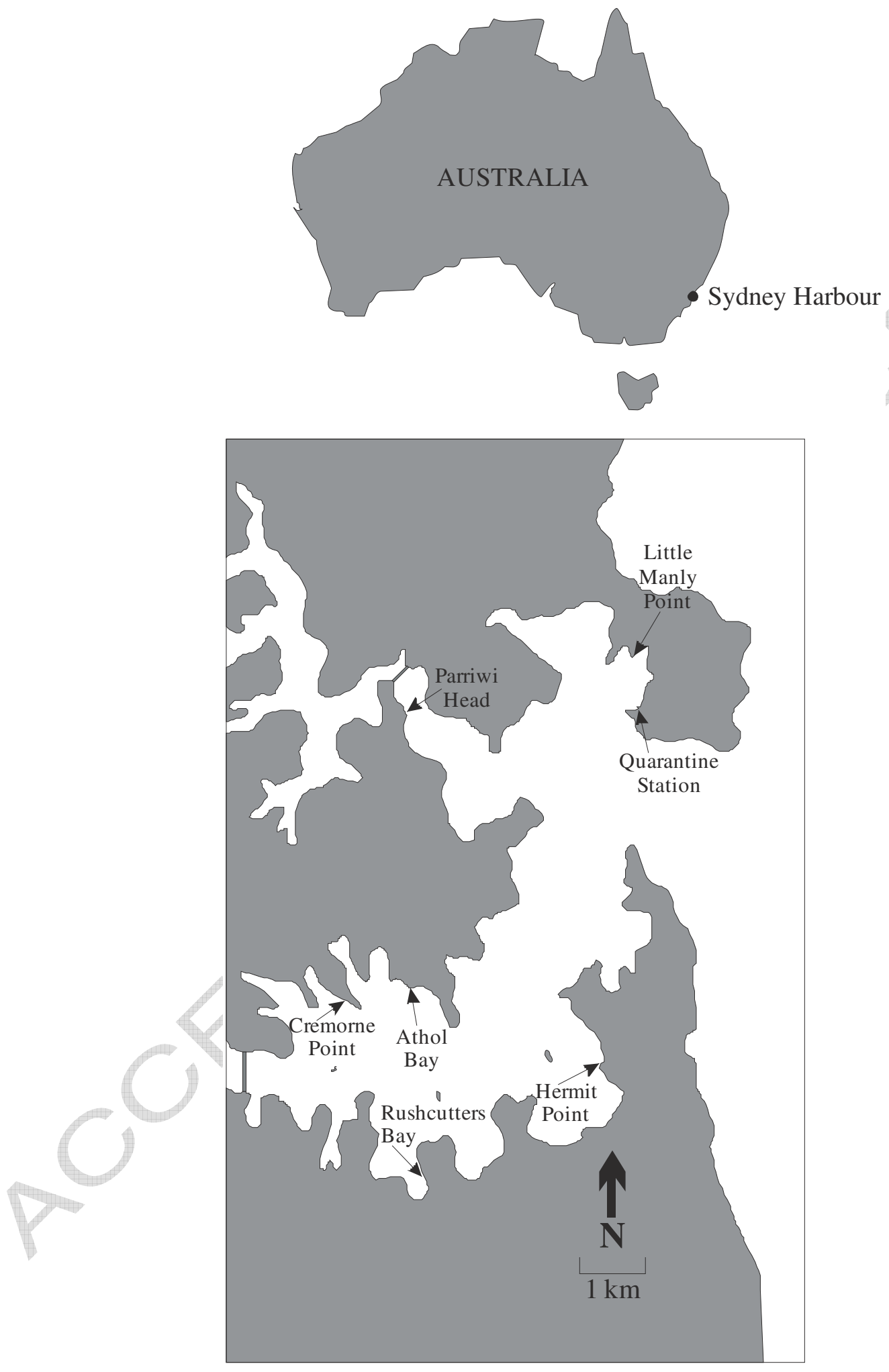
Fig. 2

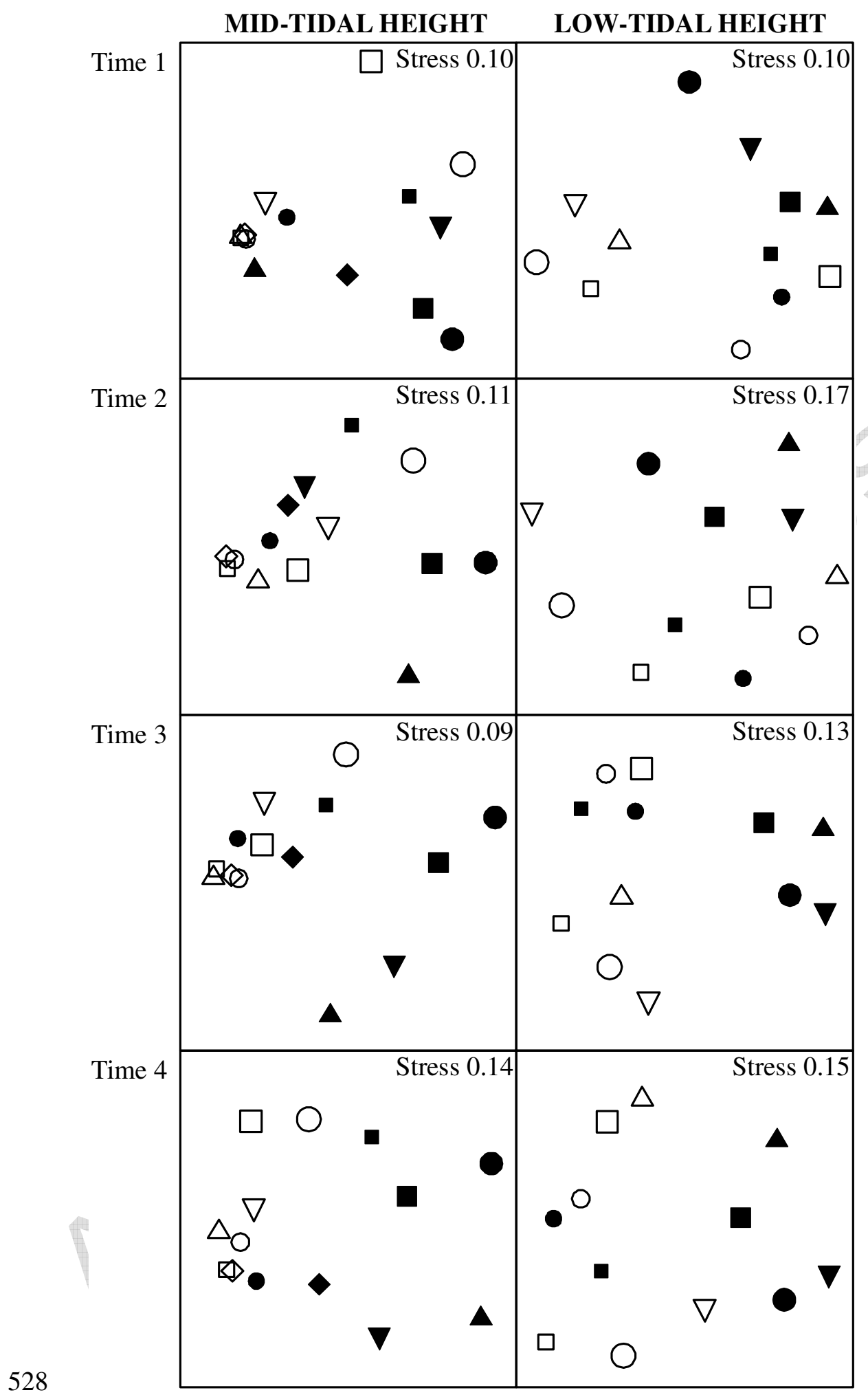


Fig. 3

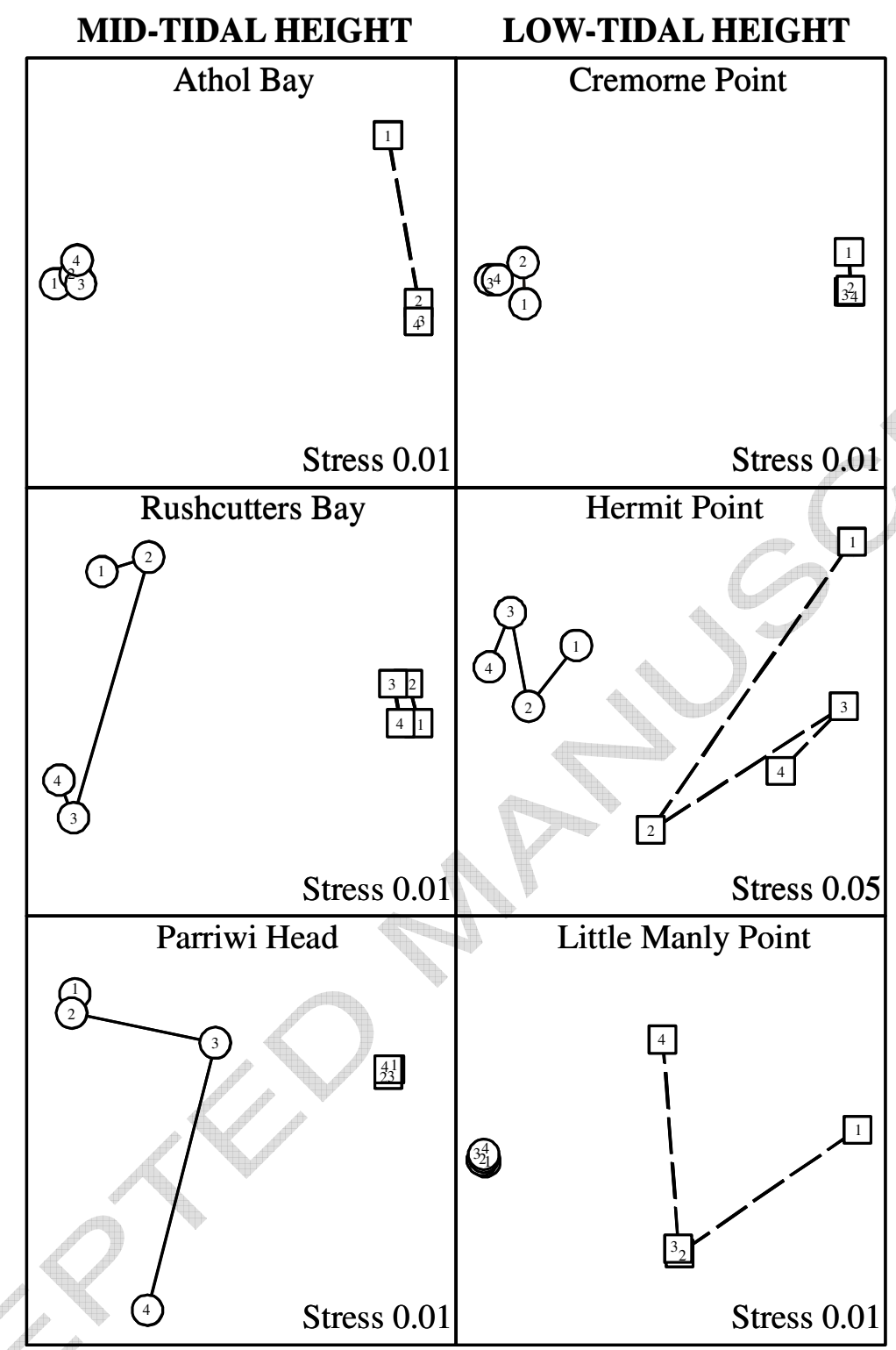


Fig .4
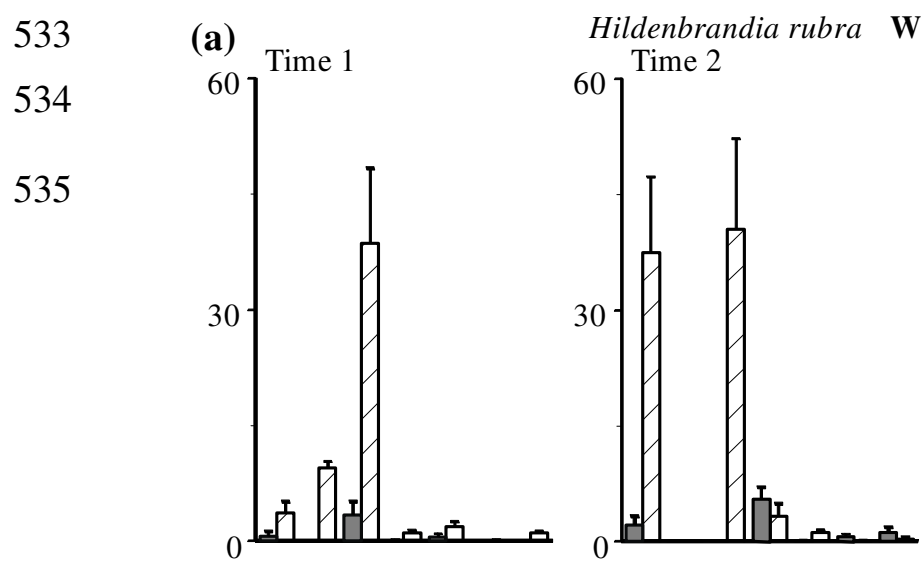

$\mathrm{W}: \mathbf{5 ( 0 )}$; NW: 21(8); $\mathrm{P}_{23}=$ **
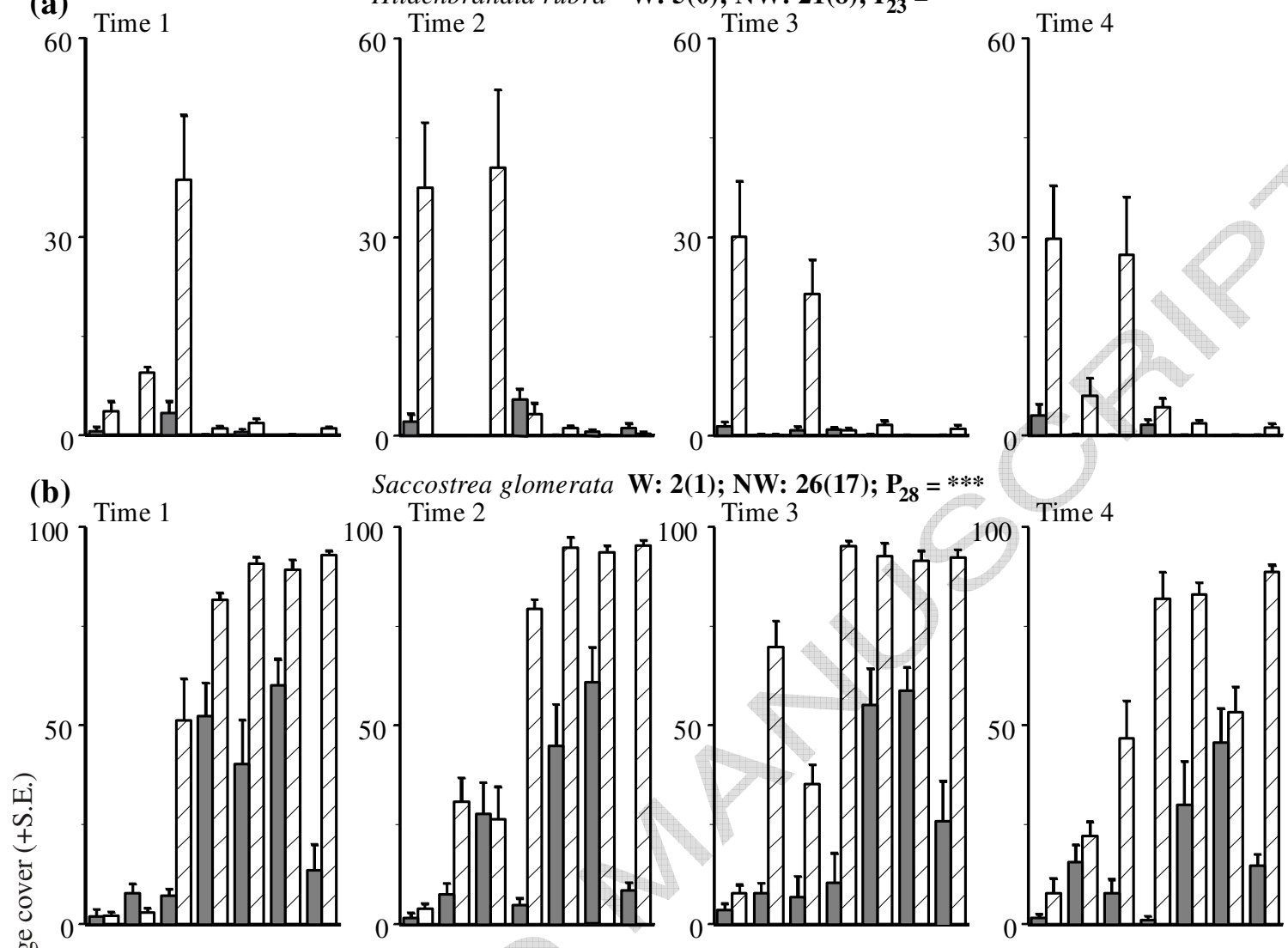

Time 2

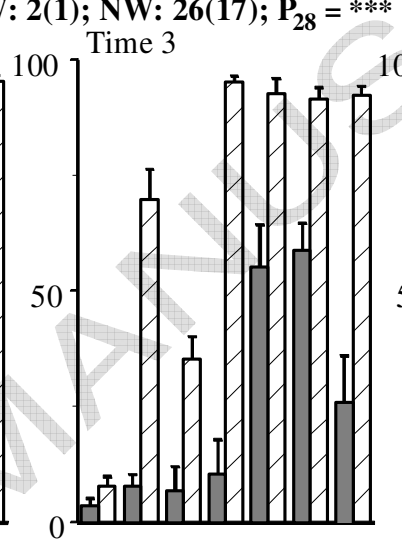

$100]^{\text {Time } 4}$
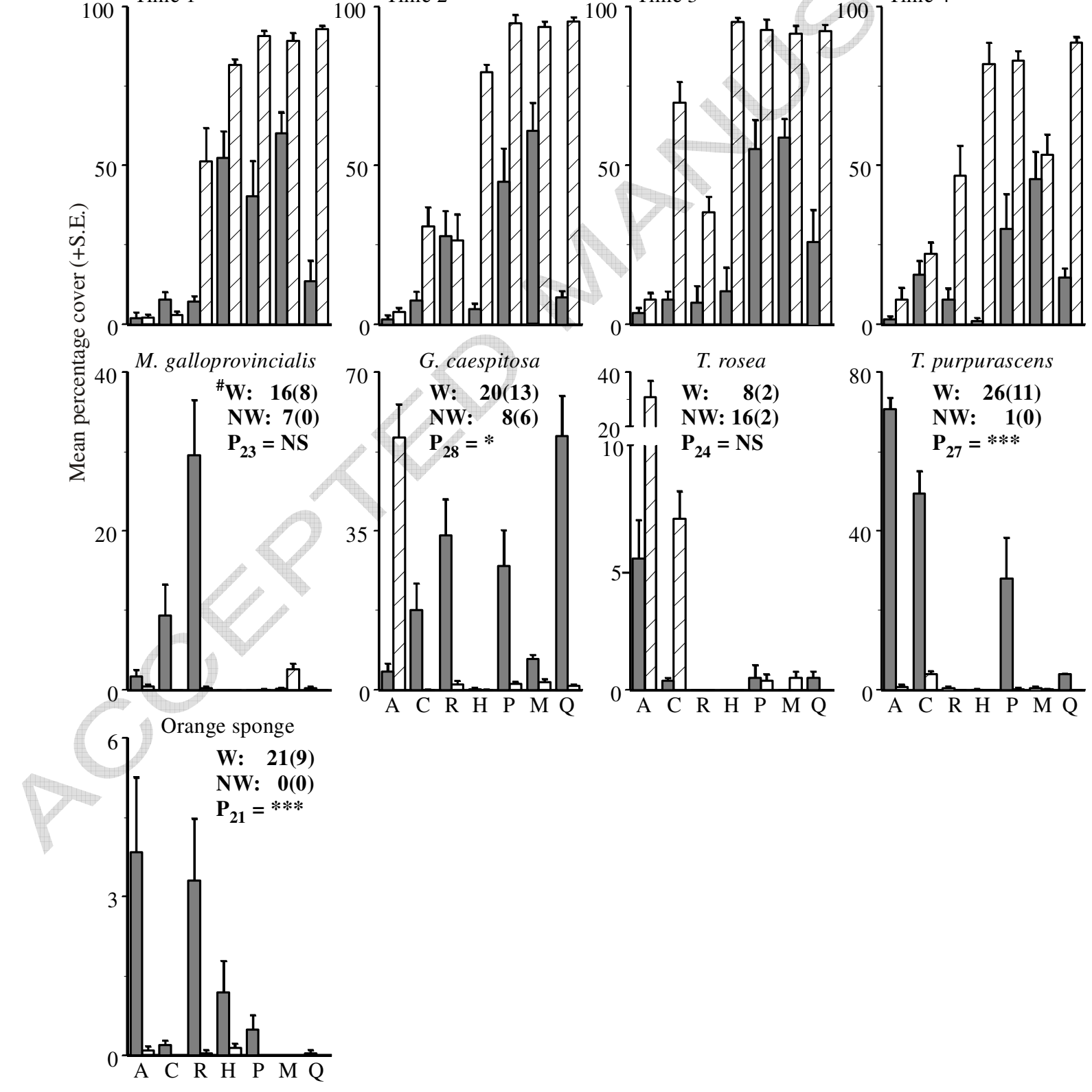
537 Fig. 5
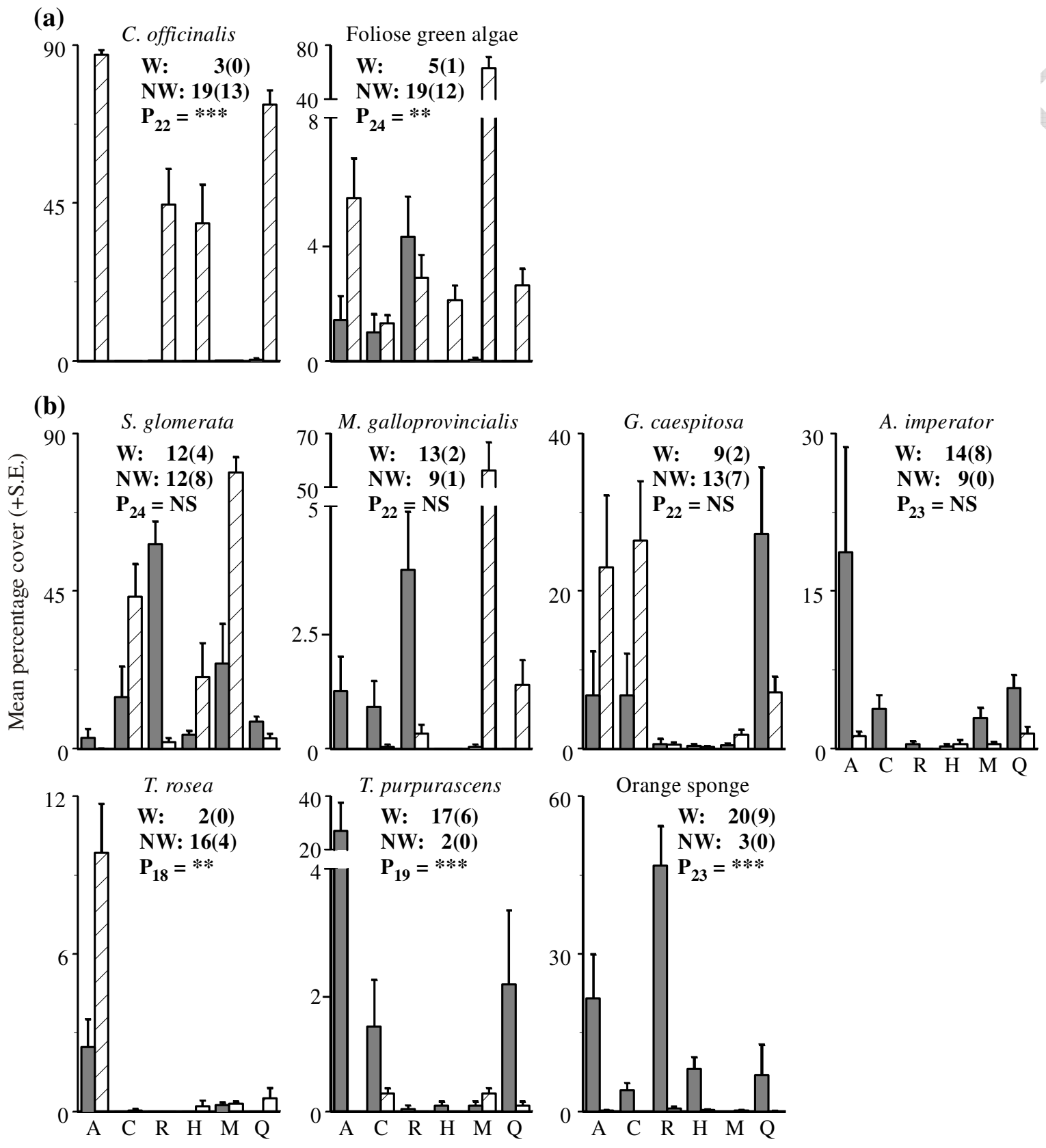
Fig. 6

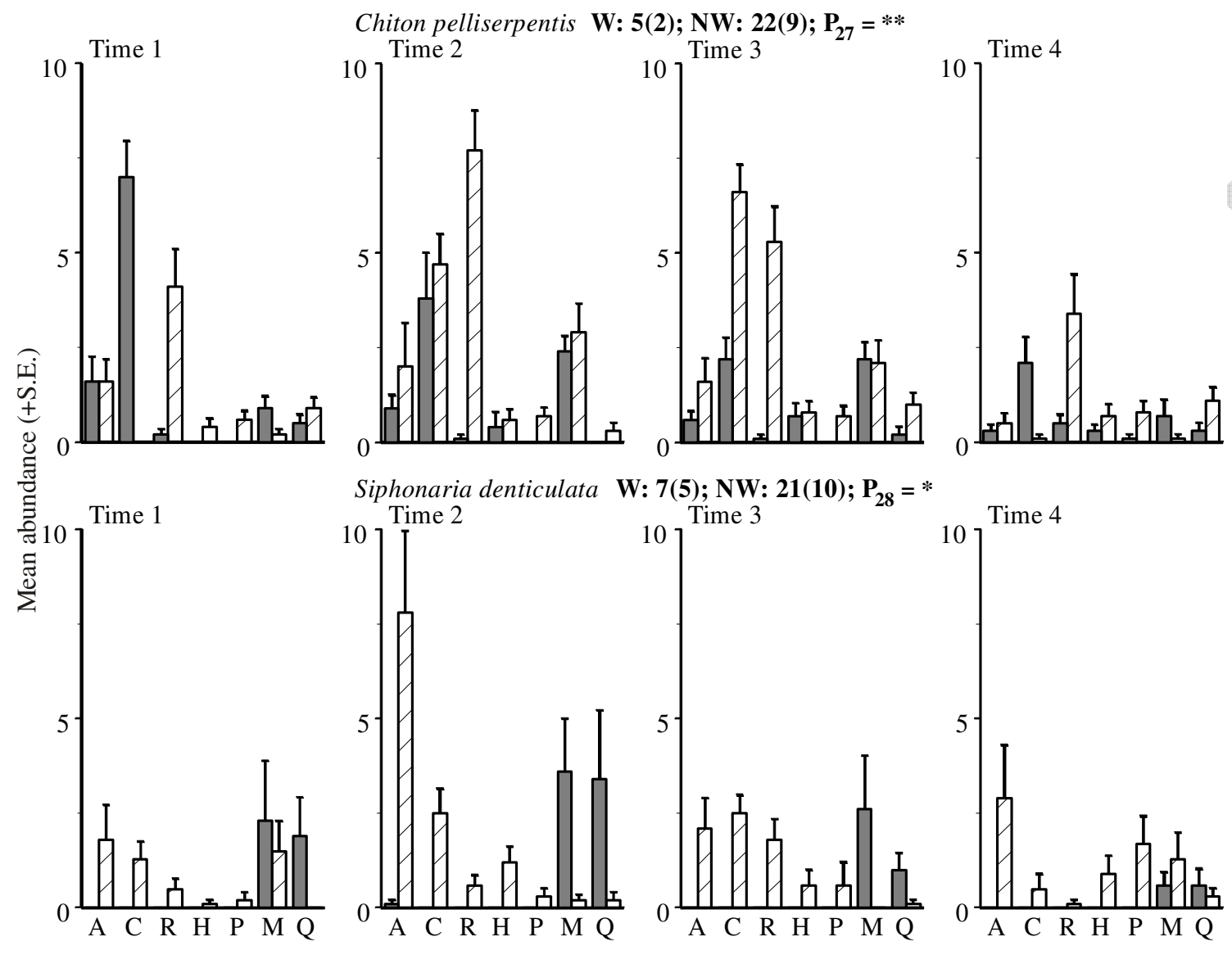


Fig. 7
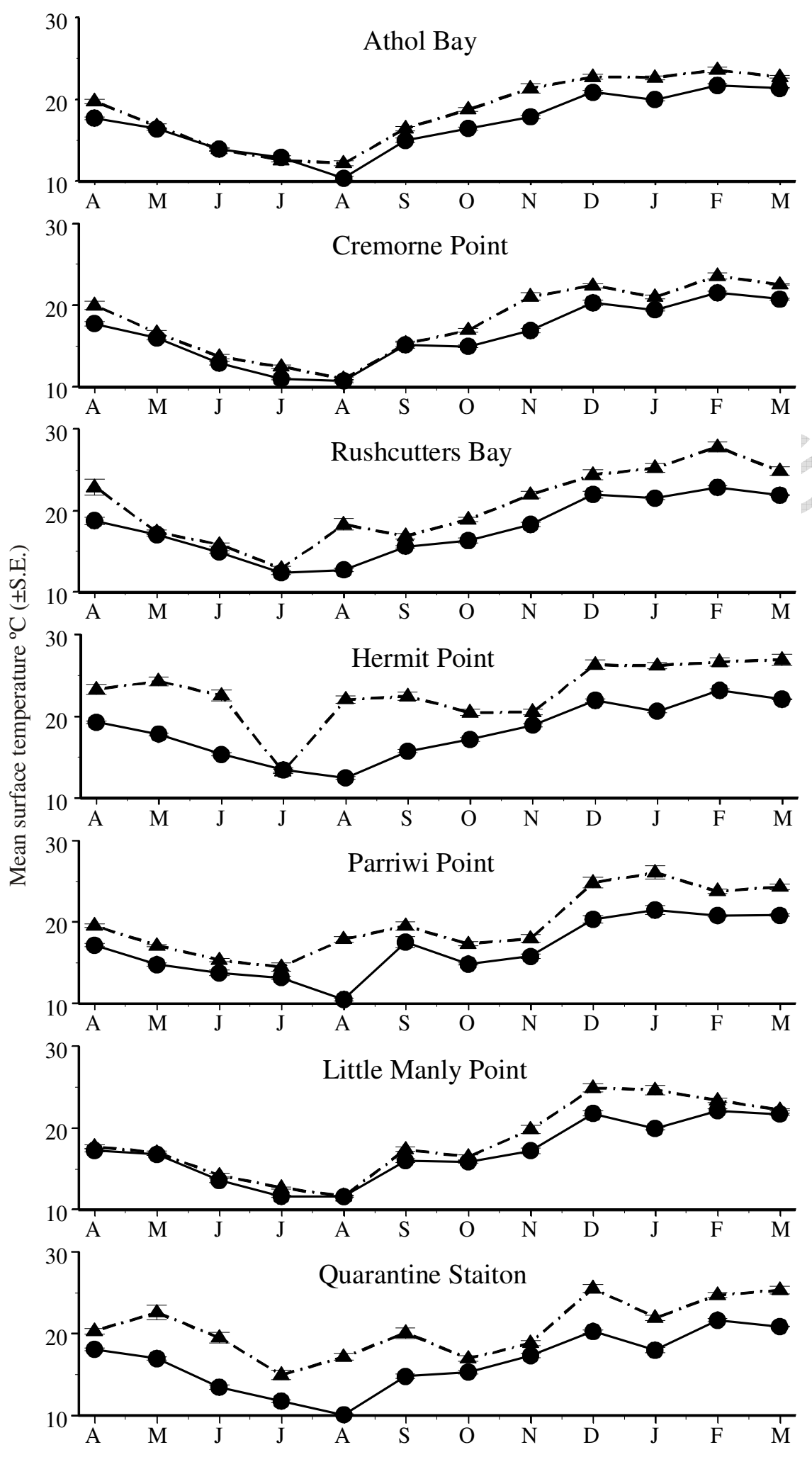
Fig. 8
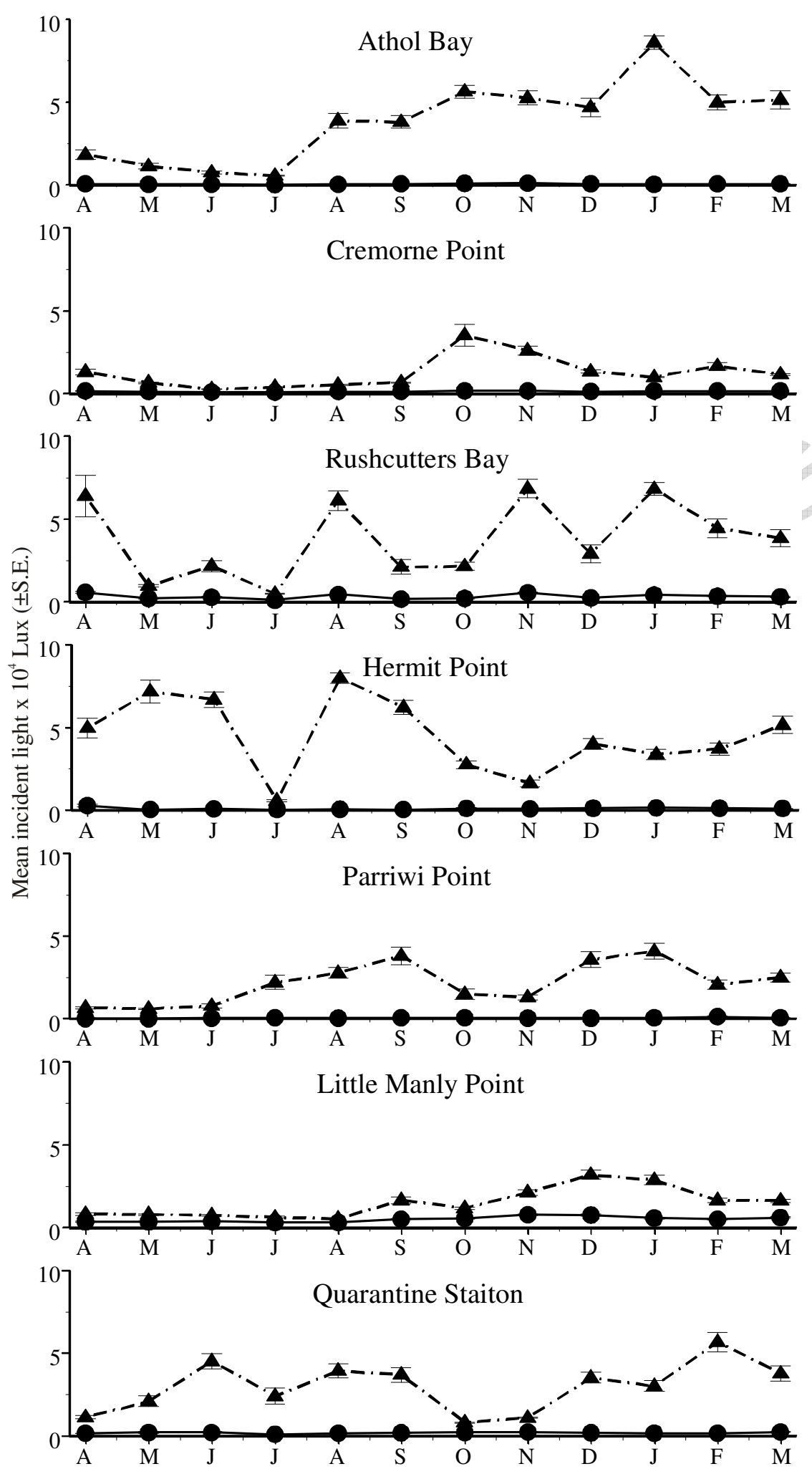